\title{
Brief Analysis of the Predicament and Outlet of Law Education
}

\author{
Wei Lin, LiPing Luo \\ School of Gannan Medical University, Jiangxi Ganzhou 341000, China \\ 1328377177@qq.com
}

Key words: law education; scientization; academic freedom; teaching;

\begin{abstract}
Law education in China experiences more than thirty years of development, and has formed a good situation with a wide range of disciplines, reasonable professional level, and common advance of legal academic degree and professional degree. In the current complex and volatile domestic and foreign environment, how to maintain this momentum will directly determine the future fate of China's law development, and also have a direct impact on the process of China's legal system. China's law education still has many problems, for example, positioning is not clear, the degree of independence is not enough, vocational skills training cannot keep up with the actual needs of social development, and excellent textbooks are few in number. Scientization of law education is an urgent requirement of the development of the times. The healthy development of law education needs the correct epistemology and methodology, and academic freedom will be conducive to creating a good atmosphere for the scientization of law education.

From the establishment of New China to the reform and opening-up, affected by the education mode of former Soviet Union, paying attention to the education of Marxism Leninism, belittling other humanistic science education, and ignoring the role of law in the society bring adverse effects to the development of law education. After the reform and opening up, with the resumption of college entrance examination system, the formulation of "developing the country through science and education" strategy and the advent of knowledge economy, the idea that only education development can help the development of other causes has become the consensus of the whole society. In the tide of economic globalization, it is an urgent need for us to speed up the realization of the scientization of law education. In view of the above understanding, the present situation of our country's law education is reflected, and on this basis, this paper puts forward some measures for the reform of law education.
\end{abstract}

\section{The main problems existing in China's law education}

(1) The overall positioning is not clear and the degree of independent development is not strong

The problem that what kind of education the law education should be in the end is still not clearly defined, which is specifically shown in three aspects: the law education should be the general education or the professional education? Now in the national institutes of law, the law education should be the elite education or mass education? Law education belongs to the scope of humanistic education or science education or both? Now the law education as general education makes the law separated from the professional function. High-level law education should be supported by a large proportion of high-level talents, including legum magister, doctor of jurisprudence and post doctoral education, which should be the responsibility of the political and legal institutions. The so-called "high level" means that the relevant courses should be fine and the training programs should be specialized, instead of the surface layer just embodied in the master, $\mathrm{PhD}$ and post doctoral titles.

China's law education is to continue the main introduction of "Western Learning" or highlight its own role according to the actual needs of the construction of legal system in China? "China's law" should be displayed in multiple ways with the view of tolerance of different academic tendency or continue to outshine others? If you choose to continue to translate the juristal works of western developed countries mainly, then, it is equivalent to the recognition of a premise that western knowledge and legal theory can become a better solution and reference to local problems in 
China. From the actual situation, since the beginning of modern times, the development of the disciplines in China basically has been westernized. Even, the disciplines of literature and history handed down from 5000-year history of civilization are largely "westernized" from the concept to the research paradigm. So, the law, which does not account for much proportion of the traditional Chinese culture, is greatly influenced by the western culture. In a sense, actually there is only "Western Jurisprudence in China", and no real China's Jurisprudence. And the so-called process of "democratization, legalization" and "globalization" is the product of the evolution of western social structure in the final analysis. This even more deepen the logic that we have to use western law to solve the problems in China. However, the nature of China's problems still must be seen by standing in the domestic point of view, irreplaceable in many situations, and China's problems surely need to be solved in a Chinese style.

In the country, China, which has a long history and complex geopolitical relations, local factors in the law construction exist largely. Simply relying on the "legal transplant", people's psychological recognition can only be obtained in the rules of law and other fields, but it is difficult to enter people's communication field together with the rules of law. This fact stimulates some jurists to pay attention to China's problems all the time, conduct research on Chinese law, and create the law different from that introduced from the west. Although in this process, it is inevitable to borrow legal terms and law the law from the west, out of inner concern, they are really facing China's problems, and seeking the new research paradigm of law in solving the China's problems in the process. This kind of deeply concern over China's problems and the innovation of legal research methods based on solving China's problems should be the direction of efforts of China's jurists. On the one hand, that Chinese jurists cannot get rid of the cultural complex determines their own direct attitudes and deep concern for China's problems; on the other hand, the conclusion can be drawn from the basic fact that China has $1 / 5$ of the world's population: China's problems not only belong to China, but also belong to the world, which requires reviewing China's problems from the perspective of the world to provide method reference. Therefore, the opinion that as long as we translate enough western legal works, Chinese legal construction problems, even China's law problems itself can be smoothly done or easily solved, even if we cannot say that it is unrealistic, at least are too optimistic. Therefore, it is necessary to fully emphasize the brave exploration and outstanding contribution of China's contemporary jurists to the legal system constriction.

(2) The mode of law education is single, and teaching materials are uneven, some good and some bad

The current law education in China generally lacks vocational skill training, and has not been able to systematically provide sufficient guidance on vocational skills, specifically shown as follows: case teaching and simulation teaching are still in the exploratory stage and has not yet formed paradigms; due to limitation of class arrangements as well as implementation and operation inconvenience, serious shortage of attention has been paid to practice etc.. There is a huge gap between the low starting point of law education and the high-quality requirements for legal profession. No better way has been found on how to overcome this contradiction. Without a good grasp of professional skills, it difficult for judges, prosecutors and lawyers to adapt to the requirements of legal profession.

For young college students first entering into the legal threshold, the textbook is tantamount to the basic guarantee for them being qualified legal talents. In the jurisprudential circle, the so-called national textbook compilation has become the monopolistic "patents" of some experts recognized by some departments, the departments, and the publisher. What's more, these materials often meet some special requirements of departments and become the "specially appointed textbooks". Even if there are a lot of "local teaching materials" with local characteristics, they also have to keep up with the situation. It is limited to this situation that the "local teaching materials" spread unchecked except the "national textbooks". At the same time, a variety of teaching materials are mixed together, while very few are really good recognized by industry experts and students. In addition, in China's law education, the judicial ethics is quite missing. One of the characterizations is that the employed judges, lawyers and other legal practitioners, in the face of numerous conflicts and 
contradictions, cannot take their own benefits as the standard. That is to say, in the face of conflict, the first choice is to take benefits as a starting point, which shows that the level of the people's judicial ethics is still not high enough, while prosecutors, lawyers and other legal professionals who do not have the quality of judicial ethics cannot be defined as the qualified legal workers. Therefore, the formation of a stable choice orientation in no connection with their own interests should be one of the main objectives of the training of the quality of judicial ethics.

Education itself is a systematic engineering, and law education is also the case. The ethical education in preschool age and the cultivation of the legal consciousness in compulsory education stage are essential for law students to understand the spirit of law, grasp the legal skills and apply the law into practice in the future.

\section{The direction of the reform of law education concept}

(1) The scientization of law education is the inevitable requirement of the times.

The rapid development of globalization and the shortage of resources have become an indisputable fact and also the biggest obstacle to the economic development of all countries. The era of knowledge economy makes people recognize that the best way to solve this problem is to develop human intelligence, because the growth of knowledge is infinite and knowledge provides an opportunity for human beings to overcome the growth of material wealth. The drive of sustainable development of knowledge economy depends on the power of human intelligence and the release of creative power. All decisions are based on knowledge as a priority. And law education is bound to become the best way to obtain legal professional knowledge and social knowledge, which itself must be "scientific" constantly. The scientization of law education is an important aspect of China's response to globalization.

Law as a science tries to train the scientific way of thinking. In order to achieve this goal, it must conform to the laws of science, that is, the law of human cognition. The scientific task is particularly important to law education. The fact tells us that the road to scientization of law education is still very long.

(2) The development of law education needs correct epistemology and methodology

Science is to seek truth: "science is to seek the real thing and to seek the essence of things through the phenomenon" (Di Cigen). Scientization is not only to popularize the common sense about science or make up the gap, but emphasize scientific spirit to make people abandon prejudice, coy and blind follow, and eliminate dogma, rigidness and vulgar science. Science should be rational, that is, through the logic and speculation, systematically to collect information, and repeat verification and reflection on the relationship between theory and practice. The science of law is the same, aiming to seek the truth. For the legal knowledge, the legal method is the embodiment of the human thought structure. Methods are derived from skills and should be tested by practice. The right methodology reflects the regularity of the ideological activities: the dynamic development process constantly repeats, obtaining knowledge from the understanding, and coming to the unknown from the known. The cognitive process is the process of subject of knowledge integrating different experience to be used in practice. The scientific spirit of methodology lies in the new discovery after accurate observation. The hypothesis theory and the experience for certification are used to expand the new field of knowledge. This was originally a research method for natural science, but it can be used as a reference for the legal science. In addition to obtaining knowledge through the logical inference, the more important knowledge comes from the truth from practice. One of the educational policies was put forward in the Communist Manifesto, that is, to link education with production practice. Science can only obtain its own development in practice. Therefore, it can be said that practice is not only the content of education, but also an important way to realize the scientific education.

(3) Academic freedom is the guarantee of the "scientization" of law education

The respect for knowledge and talents is the basic premise of the scientization of law education. And only the institutionalization of academic freedom can effectively protect the premise. Therefore, academic freedom should be a long-term and stable educational policy. To promote 
academic criticism improves the quality of scientific research and teaching. Teachers and students talk about the truth only in the academic level, yet without bias in work and profession. Academic criticism should be honest, purely academic and comprehensive. Students should be encouraged to keep questioning spirit, maintain independent opinion, and defend academic authority. Academic freedom is the sum of all the subjects involved in academic activities. There is a problem that must be paid attention to: in the market economy, the new teacher-student relationship should have a clear role definition. We should abandon the traditional "once a teacher, always a father", also oppose the general proposition of being "student-oriented", and oppose that the teacher-student relationship becomes the relationship between boss and employee. The relationship between teachers and students has already been decided by the nature of education. "Preaching, teaching and answering" is the teacher's responsibility and also the teacher's right, which does not affect the equality between teachers and students in moral quality.

\section{Constructive concept of law education}

(1) To establish the modern teaching concept and individualized training direction of law education

Teaching concept dominates teachers' teaching process, and determines the teaching method and the attitude adopted by teachers in teaching activities. The traditional teaching concept believes that teachers are the core of teaching, classroom is a necessary place for teaching, books are the main teaching content, the students are regarded as passive tools receiving education, and that scores are regarded as the standards for evaluating the school education, teachers' teaching and students' achievement. The results are a serious obstacle to the positive thinking of students and ignoring the improvement of ability, which will inevitably lead to high scores and low ability, not conducive to the growth of new people. However, modern teaching concept has abandoned the old ideas and methods. The modern teaching concept requires viewing teacher-student relationship with the view of development, focusing on mobilizing students' initiative to learn, teaching students learning method, cultivating students' ability to solve practical problems and cultivating students' ability of continuous learning, exploration and innovation, in order to adapt to the changing society.

(2) To protect fair right to education and equal entry threshold

Under the premise of ensuring the equality of the right to education, restrictions on the admission to law major should be implemented. In this regard, from the New China to the present, a lot of efforts on the realization of educational equality have been made, achieving remarkable results. The current constitution of our country stipulates: "the citizens of People's Republic of China are equal before the law". The right to education is a constitutional right, and the Chinese citizens should enjoy equal right. Market economy requires every participant to compete on a fair starting point. One aspect of ensuring fair competition is the equality of educational opportunity. In the case of limited resources of higher education, the only way to achieve a fair allocation of limited resources is to link the "admission" with "academic performance". But in reality, equality is not absolute. But in the whole society there should be a consensus that the state must mobilize and allocate available educational resources to the greatest extent so that more young people' talent can be forged.

\section{References}

[1] Ma Chongming. China's Modernization Process [M]. Beijing: Economic Science Press, 2003

[2] Gan Yang. Two Central Aspects of University General Education [J]. Reading, 2006,

[3] Qiang Shigong. Legal System and Legal Principle -- the Law of the State Transition [M]. Beijing: China University of Political Science and Law press.2003 